\title{
Wood-ash recycling affects forest soil and tree fine-root chemistry and reverses soil acidification
}

\author{
I. Brunner ${ }^{1,2}$, S. Zimmermann ${ }^{1}$, A. Zingg ${ }^{1} \&$ P. Blaser ${ }^{1}$ \\ ${ }^{1}$ Swiss Federal Institute of Forest, Snow and Landscape Research WSL, Zürcherstrasse 111, CH-8903 Birmensdorf, \\ Switzerland. ${ }^{2}$ Corresponding author*
}

Received 24 December 2003. Accepted in revised form 12 March 2004

Key words: molar BC/Al ratio, Picea abies, soil acidification, soil and fine root elements, sustainable forest management, wood ash

\begin{abstract}
Wood ash was applied to a forest ecosystem with the aim to recycle nutrients taken from the forest and to mitigate the negative effects of intensive harvesting. After two years, the application of $8,000 \mathrm{~kg} \mathrm{ha}^{-1}$ of wood ash increased soil exchangeable $\mathrm{Ca}$ and $\mathrm{Mg}$. Similarly, an increase in $\mathrm{Ca}$ and $\mathrm{Mg}$ in the Norway spruce fine roots was recorded, leading to significant linear correlations between soil and root $\mathrm{Ca}$ and soil and root $\mathrm{Mg}$. In contrast to these macronutrients, the micronutrients $\mathrm{Fe}$ and $\mathrm{Zn}$ and the toxic element $\mathrm{Al}$ decreased in the soil exchangeable fraction with the addition of wood ash, but not in the fine roots. Only Mn decreased in soil and in fine roots leading to a significant linear correlation between soil and root Mn. In soil, as well as in fine roots, strong positive correlations were found between the elements $\mathrm{Ca}$ and $\mathrm{Mg}$ and between $\mathrm{Fe}$ and $\mathrm{Al}$. This indicates that the uptake of $\mathrm{Mg}$ resembles that of $\mathrm{Ca}$ and that of $\mathrm{Al}$ that of $\mathrm{Fe}$. With the wood ash application, the $\mathrm{pH}$ increased from 3.2 to 4.8, the base saturation from $30 \%$ to $86 \%$, the molar basic cations/Al ratio (BC/Al) of the soil solution from 1.5 to 5.5 , and the molar $\mathrm{Ca} / \mathrm{Al}$ ratio of the fine roots from 1.3 to 3.7. Overall, all below-ground indicators of soil acidification responded positively to the wood ash application within two years. Nitrate concentrations increased only slightly in the soil solution at a soil depth of 75-80 cm, and no signs of increased heavy metal concentrations in the soils or in the fine roots were apparent. This suggests that the recycling of wood ash could be an integral part of sustainable forest management because it closes the nutrient cycle and reverses soil acidification.
\end{abstract}

\section{Introduction}

Renewable and $\mathrm{CO}_{2}$-neutral energy sources are being increasingly exploited in European countries in order to reduce $\mathrm{CO}_{2}$ inputs to the atmosphere and to contribute to a diversified and independent energy supply. One of these energy sources is fuel wood which is burnt in communal kilns in order to generate thermal and electrical energy. With an approximately 100:1 weight ratio of fuel wood to wood ash, more than 25 million $\mathrm{kg}$ per year of wood ash are produced in Switzerland. Thus, the question arises whether the wood ash should be recycled in the forest (which is, according to current Swiss forest legislation, prohib-

\footnotetext{
*FAX No: +41-1-7392215. E-mail: ivano.brunner@wsl.ch
}

ited) or disposed of in incineration plants. Intensive forest harvesting most likely results in a depletion of soil nutrients and as a consequence in an accelerated soil acidification (Olsson et al., 1996), which could justify the recycling of wood ash.

In recent decades, forest soil acidification has also been accelerated by acidic deposition at sensitive sites in forested landscapes (Driscoll et al., 2001; Fowler et al., 1999). The composition of acidic deposition includes ions, gases, and particles derived from gaseous emissions of sulfur dioxide $\left(\mathrm{SO}_{2}\right)$, nitrogen oxides $\left(\mathrm{NO}_{\mathrm{x}}\right)$, ammonia $\left(\mathrm{NH}_{4}\right)$, and particulate emissions of acidifying and neutralising compounds (Driscoll et al., 2001). Although atmospheric deposition of sulfur has decreased over the last 30 years due to reduced emissions of sulfur dioxide (Palmer and Driscoll, 2002), 
the remaining acid deposition can still lead to a depletion of base cations (Rohde et al., 2002) or to accelerated soil acidification coupled with an increase in aluminium concentrations (Blaser et al., 1999). The consequences can be an increase in the incidence and severity of aluminium toxicity, aluminium antagonism, and nutrient imbalances in forest tree species (Cronan and Grigal, 1995), as observed e.g. with red spruce or sugar maple in the north-eastern United States (Driscoll et al., 2001; Sharpe, 2002).

The application of wood ash to forest ecosystems can alter the chemistry of soils (Arvidsson and Lundkvist, 2003; Bundt et al., 2001b; Eriksson, 1998; Rumpf et al., 2001), of soil solutions (Ludwig et al., 2002), of fine roots (Genenger et al. 2003c), and of needles (Arvidsson and Lundkvist, 2002; Hallenbarter et al., 2002). Thus it can also potentially affect the indicators of soil acidification. Based on the concept of critical loads of acidity, the main indicators of soil acidification are the molar ratio of the basic cations $(\mathrm{BC} ; \mathrm{Ca}+\mathrm{Mg}+\mathrm{K})$ to $\mathrm{Al}(\mathrm{BC} / \mathrm{Al})$ in the soil solution (Sverdrup and Warfvinge, 1993), $\mathrm{pH}$ and percent base saturation (BS) of the soil matrix, and the molar $\mathrm{Ca} / \mathrm{Al}$ ratios of fine roots and current foliage of the trees (Cronan and Grigal, 1995; Hettelingh and de Vries, 1992). If so, the recycling of wood ash and thus of elements could be an integral part of sustainable forest management. In the present study, the focus is on the relationship between soil and tree fine-root elements. Both parameters are used as acidification indicators, but the relationships of the elements with each other and in particular after treatments such as wood ash has, until now, only been poorly studied.

\section{Materials and methods}

\section{Experimental site}

The experiment was conducted in a Norway spruce (Picea abies (L.) Karst.) forest on the Swiss Plateau, $25 \mathrm{~km}$ north west of Zurich, Switzerland (N $47^{\circ} 30^{\prime} 34^{\prime \prime} / \mathrm{E} 08^{\circ} 20^{\prime} 50^{\prime \prime}$, $464 \mathrm{~m}$ a.s.1.), with a 15 -year average annual precipitation of $1,076 \mathrm{~mm}$ and a mean air temperature of $9.6^{\circ} \mathrm{C}$. The 60 - to 70 -year-old stand is classified as a Galio odorati - Fagetum luzuletosum (Ellenberg and Klötzli, 1972) stand but is dominated by Norway spruce. The stand has a density of 440 trees $\mathrm{ha}^{-1}$, with the stems evenly distributed, and with the stems having a mean diameter of $34.6 \mathrm{~cm}$ at breast height. The soil is an acidic brown earth
('Dystric cambisol'; see also Bundt et al., 2001a). The topsoil is characterised by low $\mathrm{pH}$ (3.3), low levels of $\mathrm{C}\left(44.0 \mathrm{mg} \mathrm{g}^{-1}\right)$ and $\mathrm{N}\left(2.7 \mathrm{mg} \mathrm{g}^{-1}\right)$, a low cation exchange capacity (CEC, $96 \mu$ mol $_{\mathrm{c}} \mathrm{g}^{-1}$ ) and base saturation (BS, 32\%), low exchangeable Ca $\left(24.7 \mu \mathrm{mol}_{\mathrm{c}} \mathrm{g}^{-1}\right)$ and $\mathrm{Mg}\left(4.0 \mu \mathrm{mol}_{\mathrm{c}} \mathrm{g}^{-1}\right)$, and high exchangeable $\mathrm{Al}\left(46.3 \mu \mathrm{mol}_{\mathrm{c}} \mathrm{g}^{-1}\right)$ (Zimmermann and Frey, 2002). The experiment was set up as a random block design with four treatments and four replicated plots, resulting in a 0.8 ha investigation area (see also Genenger et al., 2003c). The area was devided into 16 plots of about $500 \mathrm{~m}^{2}$ with having 22 trees in the mean. The experimental variable was the application or non-application (=control) of wood ash. Two further treatments were irrigation with a liquid fertiliser and irrigation with stream water (data not shown). $4,000 \mathrm{~kg} \mathrm{ha}^{-1}$ wood ash, derived from wood-chip combustion of untreated fuel wood from mixed forest stands, was applied by hand twice, once in May 1998 and again in July 1999 , so that a total of $8,000 \mathrm{~kg} \mathrm{ha}^{-1}$ was applied. This application meant that the following amounts of elements were added $\left[\mathrm{kg} \mathrm{ha}^{-1}\right]$ : $\mathrm{Ca} 2,300$, $\mathrm{K} 460, \mathrm{Mg}$ 150, P 130, S 52, Al 46, Fe 40, Mn 38, Zn 1.9, Cu 1.1, Ni 0.25, Pb 0.20, Cr 0.10, and Cd, Co, Mo 0.02 . The amount of $\mathrm{C}$ added was $0.03 \mathrm{~kg} \mathrm{ha}^{-1}$ and that of $\mathrm{N}<0.01 \mathrm{~kg} \mathrm{ha}^{-1}$.

\section{Soil, fine root, and needle sampling}

Samples of soil and fine roots were collected in April in 1998 and 2000. The samples were taken independently of the plot design in a $5 \times 5$-m grid over the investigation area (see Genenger et al., 2003c). At each sampling point, three soil cores $(10 \mathrm{~cm}$ in depth, $8.5 \mathrm{~cm}$ in diameter) were collected. The soil consisted of two horizons: the topsoil (Ah; the uppermost mineral soil layer, characterised by an accumulation of humified organic matter) and the mineral soil (B; mineral soil layer formed below the Ah horizon). Each horizon from all three cores was pooled separately. The samples were sieved, and the fine roots $(\leq 2 \mathrm{~mm}$ in diameter) of Norway spruce were isolated from each bulk sample and washed. The soils and fine roots were dried at $60{ }^{\circ} \mathrm{C}$ for at least 3 days. Needles were sampled in the winters (December, January) of 1997/98 and 1999/2000 from 136 selected trees within the experimental site (see Hallenbarter et al., 2002). Trees were located at a minimum distance of $4 \mathrm{~m}$ from the neighbouring treatment plot. One hundred medial needles were taken from a shoot from the uppermost 
whorl of the sample tree. Needle samples were dried at $65^{\circ} \mathrm{C}$ to constant weight.

\section{$p H$ and chemical analyses}

Between six and eight samples of the Ah horizon were taken from each plot for soil and fine-root chemical analyses. Soil $\mathrm{pH}$ was measured potentiometrically in $0.01 \mathrm{M} \mathrm{CaCl}_{2}$ and the exchangeable cations were extracted with $1 \mathrm{M} \mathrm{NH}_{4} \mathrm{Cl}$ for $1 \mathrm{~h}$ (Brunner et al., 1999). Fine roots and needles were digested in a high pressure microwave (Milestone MLS Ultraclave) (Brunner et al., 2002). Soil, fine-root, and needle elements were measured by ICP-AES (Optima 3000, Perkin Elmer) (Brunner et al., 2002).

\section{Soil solution}

The soil solution was collected from the centres of the plots with suction-cups at depths of $10-15 \mathrm{~cm}$, 20-25 cm, and 70-75 cm, where a vacuum of -600 mbar was renewed every $10 \mathrm{~h}$ (maximum rising to $-400 \mathrm{mbar}$ ). In addition, gravitation-lysimeters were installed on the soil surface below the organic litter layer at a depth of $3 \mathrm{~cm}$ (data not shown). The solution was collected every week during the growing season and every 2-4 weeks in winter. The solutions were filtered $(0.45 \mu \mathrm{m}$, Schleicher \& Schuell, ME 25) and either measured at once or stored at $-20{ }^{\circ} \mathrm{C}$ and measured later. The elements were measured by ICPAES (Optima 3000, Perkin Elmer), and all samples were analysed for nitrate by ion-chromatography (Dionex DX-120) (Genenger et al., 2003b).

\section{Statistics}

All statistical analyses were performed using StatView 5.0 (SAS Institute Inc., Cary, NC).

\section{Results}

\section{Soil and fine-root elements}

Due to the application $8,000 \mathrm{~kg} \mathrm{ha}^{-1}$ of wood ash to a Norway spruce forest stand, the soil exchangeable $\mathrm{Ca}$ and $\mathrm{Mg}$ increased approximative fourfold and $\mathrm{K}$ doubled (Figure 1). The fine root $\mathrm{Ca}$ and $\mathrm{Mg}$ in the Norway spruce also doubled, leading to significant linear correlations between the soil and root $\mathrm{Ca}$ $(r=0.83, P<0.0001)$ and between the soil and root $\mathrm{Mg}(r=0.84, P<0.0001)$ (Figure 1).
Although the concentrations of $\mathrm{K}$ increased slightly in the fine roots, a linear correlation was not found between soil and root K (Figure 1). In contrast to these macronutrients, the micronutrients $\mathrm{Fe}, \mathrm{Mn}$, and $\mathrm{Zn}$, as well as the toxic element $\mathrm{Al}$, decreased in the soil exchangeable fraction with the addition of wood ash by an approximative factor of 4 (Figure 2). This decrease is most likely linked to the increase in the $\mathrm{pH}$ of the soil matrix (from 3.2 to 4.8, Table 1). However, the concentrations of the elements $\mathrm{Fe}, \mathrm{Zn}$, and $\mathrm{Al}$ did not decrease in the fine roots. Only $\mathrm{Mn}$ was halved, leading to a significant linear correlation between the soil and root $\mathrm{Mn}(r=0.60, P<0.0001)$.

Soil exchangeable $\mathrm{Ca}$ and $\mathrm{Mg}$ were found to be strongly positive correlated both before and after the application of wood ash $(r=0.89-0.90, P<0.0001)$ (Figure 3). In contrast, $\mathrm{Ca}$ and $\mathrm{Mg}$ in the fine roots did not correlate before the wood ash application. However, after the application, $\mathrm{Ca}$ and $\mathrm{Mg}$ in the fine roots showed a strong positive correlation $(r=0.79$, $P<0.0001$ ) (Figure 3). Similarly, soil exchangeable $\mathrm{Fe}$ and $\mathrm{Al}$ strongly correlated positively both before and after the application of wood ash $(r=0.67-0.86$, $P<0.0001$ ) (Figure 4), as they did in the fine roots $(r=0.76-0.88, P<0.0001)$ (Figure 4).

\section{Indicators of soil acidification}

The wood ash application influenced the main indicators of soil acidification. The mean of the $\mathrm{pH}$ of the soil matrix increased from 3.2 to 4.8 . Those of the base saturation (BS) rose from $30 \%$ to $86 \%$, those of the molar $\mathrm{BC} / \mathrm{Al}$ of the soil solution from 1.5 to 5.5 , and those of the molar $\mathrm{Ca} / \mathrm{Al}$ ratio of the fine roots from 1.3 to 3.7 (Table 1). But the molar $\mathrm{Ca} / \mathrm{Al}$ ratio in the most recent needles did not change within the investigated time period (Table 1). With the increase in both, the soil $\mathrm{BS}$ and the root $\mathrm{Ca} / \mathrm{Al}$, the correlation between these two indicators became highly significant $(r=0.66$, $P<0.0001$ ) (Figure 5). In the soil solution at 10$15 \mathrm{~cm}$, the molar $\mathrm{BC} / \mathrm{Al}$ ratio increased constantly, although a seasonal dynamics was observed (Figure 6) mainly due to $\mathrm{Al}$ concentrations being higher during the winter months (data not shown). At a depth of 20$25 \mathrm{~cm}$, only a slight increase in the molar $\mathrm{BC} / \mathrm{Al}$ ratio was observed, and at 75-80 $\mathrm{cm}$ depth and below the surface at a depth of $3 \mathrm{~cm}$ no trends were obvious (data not shown).

In the soil solution at a soil depth of 75-80 cm, a slight increase in the nitrate concentration of the wood ash treatment was recorded, whereas in the control 

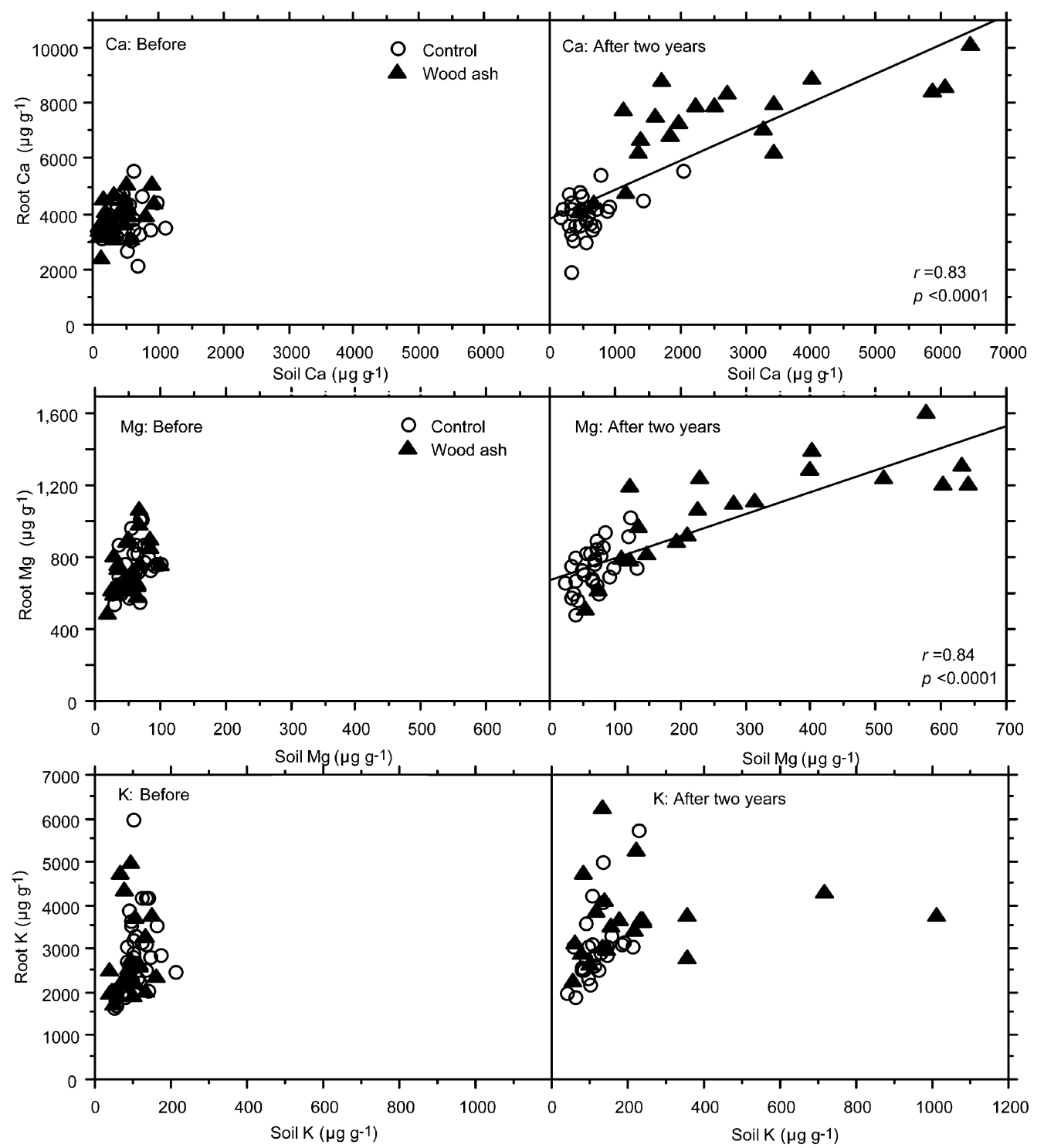

Figure 1. Relationship between soil exchangeable and fine-root macronutrients $(\mathrm{Ca}, \mathrm{Mg}, \mathrm{K})$, as recorded in the control and the wood ash treatment plots before and after two years of wood ash treatment.

treatment a fourfold decrease was evident (Figure 6). Nitrate concentrations at other soil depths were not influenced (data not shown).

\section{Discussion}

The recycling of wood ash represents an integral part of the life cycle assessment (LCA) of forest products, such as timber or fuel wood (Werner et al., 2002). LCA serves as a tool to help monitor the sustainability of forest management (Frühwald, 1995). In the present study, the aim was to recycle nutrients taken from the forest by timber harvesting. $8,000 \mathrm{~kg} \mathrm{ha}^{-1}$ of wood ash were applied, corresponding approximately to a long rotation period (145 years, 12 thinnings, 1 end harvest) when using the Swiss yield tables for Norway spruce with a site index of 27 (Badoux, 1983), a dry wood density of $430 \mathrm{~kg} \mathrm{~m}^{-3}$, and an ash content of $0.9 \%$ for timber wood without bark and branches (Noger et al., 1996). This corresponds to a total growth of $2,058 \mathrm{~m}^{3} \mathrm{ha}^{-1}$. With the application of wood ash, large amounts of nutrients were added within a short time, about $2,300 \mathrm{~kg} \mathrm{ha}^{-1}$ of $\mathrm{Ca}, 460 \mathrm{~kg} \mathrm{ha}^{-1}$ of $\mathrm{K}$, 

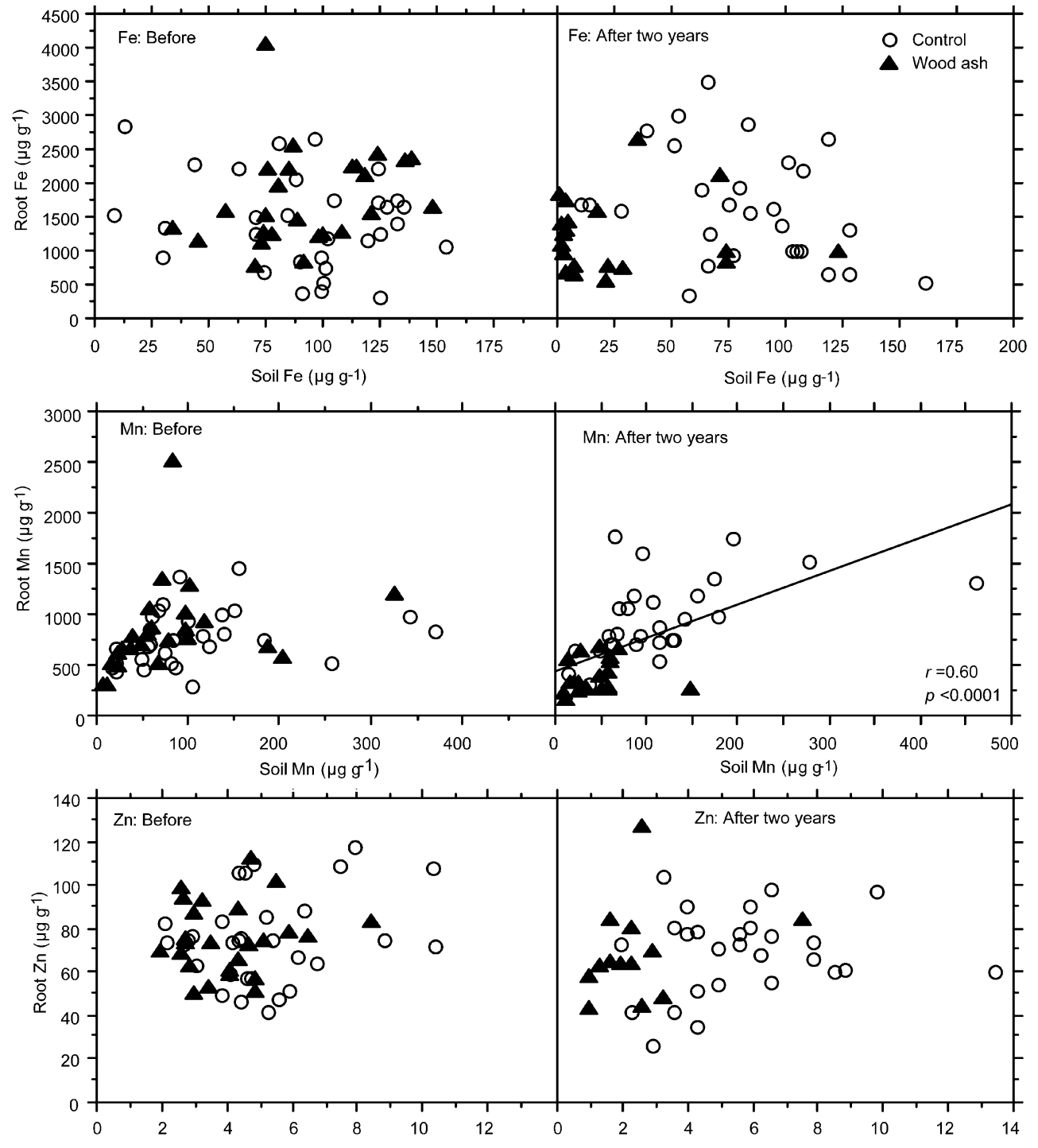

Soil Zn $\left(\mu g g^{-1}\right)$

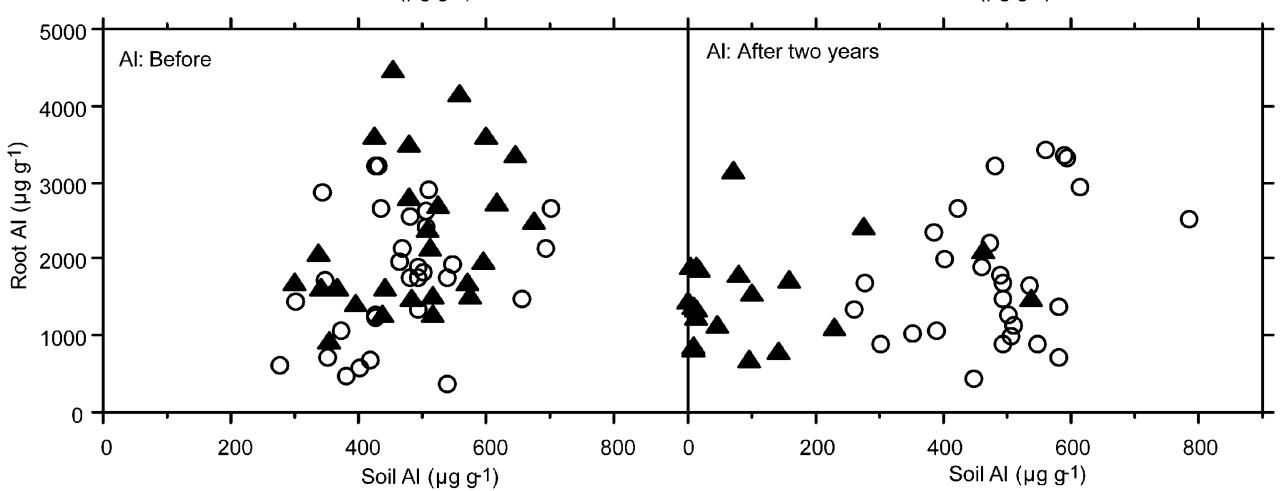

Figure 2. Relationship between soil exchangeable and fine-root metals (micronutrients $\mathrm{Fe}, \mathrm{Mn}, \mathrm{Zn}$; toxic element $\mathrm{Al}$ ), as recorded in the control and the wood ash treatment plots before and after two years of wood ash treatment. 
Table 1. Mean values of soil acidification indicators as recorded in the control and the wood ash treatment plots before and after two years of wood ash treatment. $P=$ Probability level for the one-way analysis of variance (ANOVA); $\mathrm{ns}=$ not significant $(P \geq 0.05)$. $\mathrm{n}$ of soil matrix and fine root samples: 20-31; $n$ of soil solution samples: 20-26; $n$ of needle samples: 34

\begin{tabular}{llrcc}
\hline Indicator & & Control plots & Wood ash plots & $P$ \\
\hline Before & & & & \\
pH & (soil matrix) & 3.2 & 3.2 & $\mathrm{~ns}$ \\
$\mathrm{BS}(\%)$ & (soil matrix) & 33.7 & 30.4 & $\mathrm{~ns}$ \\
$\mathrm{BC} / \mathrm{Al}$ & (soil solution) & 2.2 & 1.5 & $<0.0001$ \\
$\mathrm{Ca} / \mathrm{Al}$ & (fine roots) & 1.9 & 1.3 & 0.0364 \\
$\mathrm{Ca} / \mathrm{Al}$ & (needles) & 57.5 & 56.8 & $\mathrm{~ns}$ \\
$\mathrm{After} \mathrm{two} \mathrm{years}$ & & & & \\
$\mathrm{pH}$ & (soil matrix) & 3.3 & 4.8 & $<0.0001$ \\
$\mathrm{BS}(\%)$ & (soil matrix) & 36.3 & 85.9 & $<0.0001$ \\
$\mathrm{BC} / \mathrm{Al}$ & (soil solution) & 2.2 & 5.5 & $<0.0001$ \\
$\mathrm{Ca} / \mathrm{Al}$ & (fine roots) & 2.0 & 3.7 & $<0.0001$ \\
$\mathrm{Ca} / \mathrm{Al}$ & (needles) & 59.1 & 55.9 & $\mathrm{~ns}$ \\
\hline
\end{tabular}
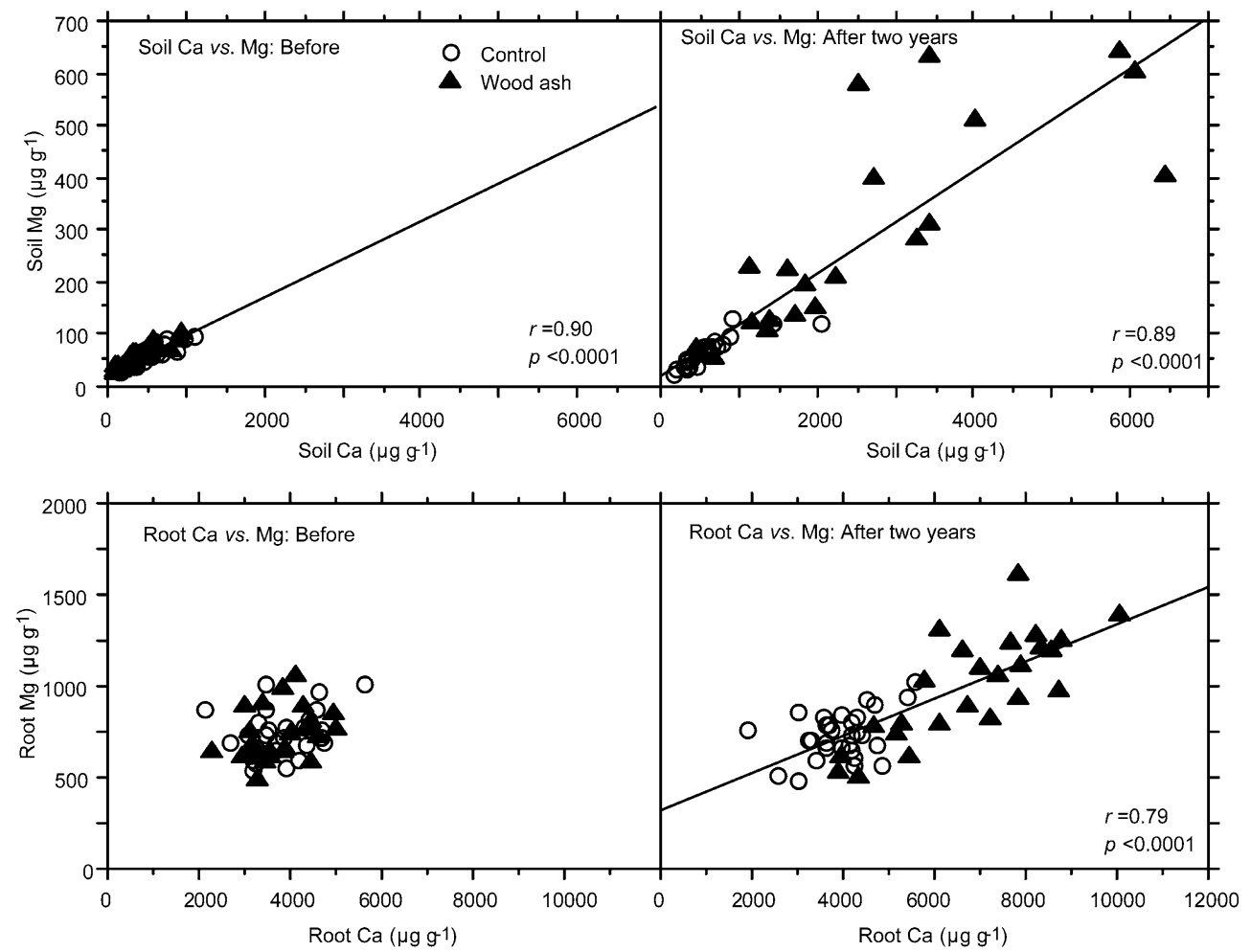

Figure 3. Relationship between soil exchangeable $\mathrm{Ca}$ and $\mathrm{Mg}$ and between fine-root $\mathrm{Ca}$ and $\mathrm{Mg}$, as recorded in the control and the wood ash treatment plots before and after two years of wood ash treatment. 

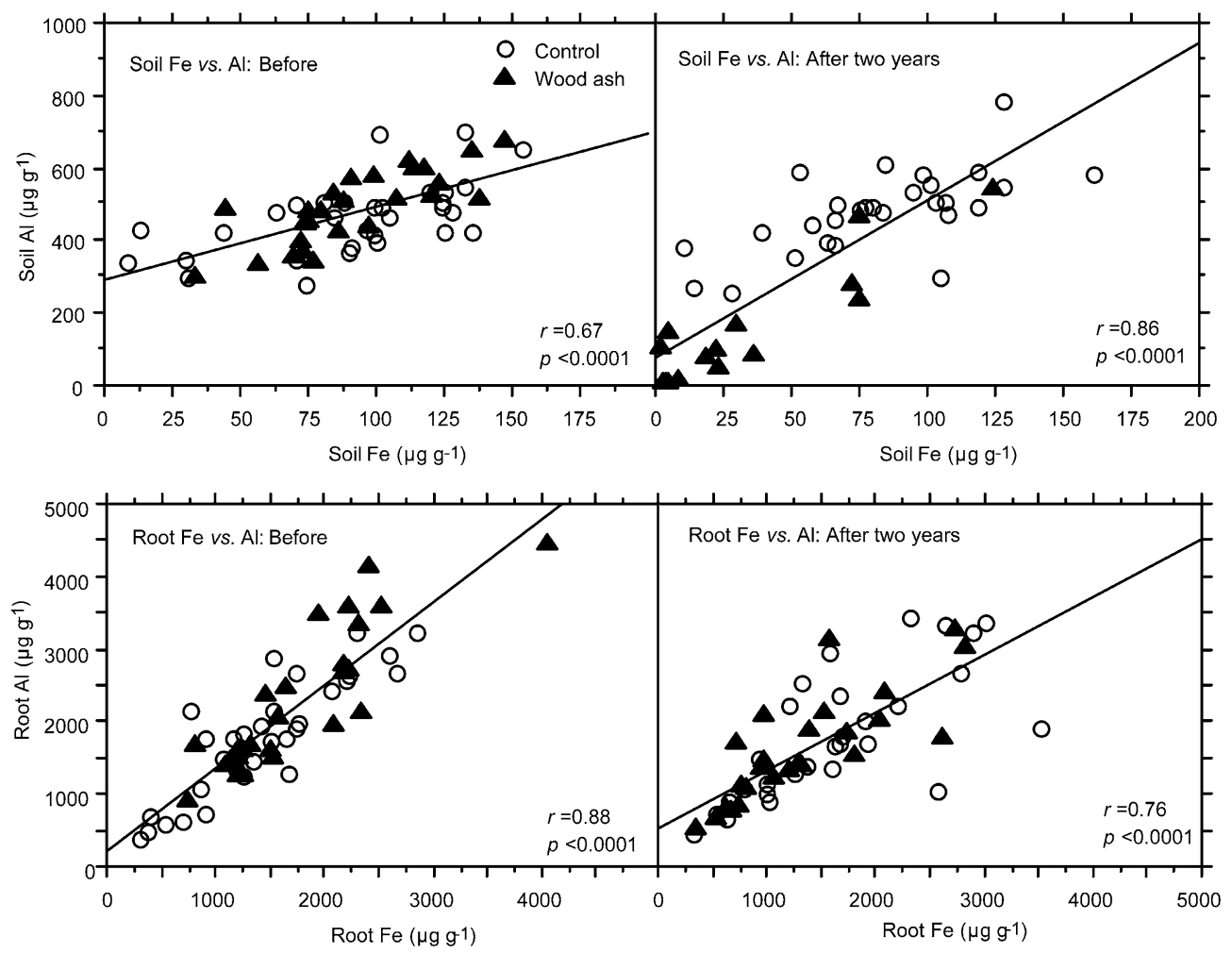

Figure 4. Relationship between soil exchangeable $\mathrm{Fe}$ and $\mathrm{Al}$ and between fine-root $\mathrm{Fe}$ and $\mathrm{Al}$, as recorded in the control and the wood ash treatment plots before and after two years of wood ash treatment.

and $140 \mathrm{~kg} \mathrm{ha}^{-1}$ of $\mathrm{Mg}$ and $\mathrm{P}$. This addition induced a wide range of alterations in the forest ecosystem, such as in the chemistry of the soils and soil solutions (Bundt et al., 2001b; Zimmermann and Frey, 2002), in the fine roots (Genenger et al., 2003c), and in the needles (Hallenbarter et al., 2002).

Our results showed that, for some elements, the chemistry of the soil is closely linked to that of the fine roots. This is partly due to the fact that fine roots additionally act as an exchange site similar to soil minerals or soil organic matter (Heim et al., 1999). This was the case for the elements $\mathrm{Ca}$ and $\mathrm{Mg}$, for which highly significant positive correlations were observed between the exchangeable fraction of the soil and the total amounts of the fine roots. Potassium is, however, a more mobile element and no such correlation was found. On the other hand, a fourfold decrease in the soil exchangeable fraction was observed for the elements $\mathrm{Fe}, \mathrm{Mn}, \mathrm{Al}$, and $\mathrm{Zn}$, even though about $40 \mathrm{~kg} \mathrm{ha}^{-1}$ of Fe, Mn, and $\mathrm{Al}$, and about $2 \mathrm{~kg} \mathrm{ha}^{-1}$ of $\mathrm{Zn}$ were added with the wood ash. A similar decrease in the exchangeability has been observed by Ludwig et al. (2002) for $\mathrm{Fe}, \mathrm{Mn}$, and $\mathrm{Al}$ after the application of $4,800 \mathrm{~kg} \mathrm{ha}^{-1} \mathrm{ash}$. This indicates that these elements were displaced from the exchange sites (mainly $\mathrm{Ca}$ and $\mathrm{Mg}$ ), and fell out in hydroxo-complexes due to the increased $\mathrm{pH}$. However, concentrations of these elements in the fine roots did not change, with the exception of Mn, which was reduced. This also indicates that the uptake of $\mathrm{Fe}, \mathrm{Al}$, and $\mathrm{Zn}$ is not dependent on soil-chemical properties, unlike with $\mathrm{Ca}, \mathrm{Mg}$, and $\mathrm{Mn}$. The uptake of $\mathrm{Fe}, \mathrm{Al}$, and $\mathrm{Zn}$ is rather dependent on the properties of the plants, e.g. strategy I or siderophores produced by mycorrhizal fungal partners (Marschner, 1995). Hahn and Marschner (1998) similarly observed an increase in the concentrations of $\mathrm{Ca}$ and $\mathrm{Mg}$ after liming, but a decrease in those of $\mathrm{Mn}$ and $\mathrm{Al}$ in the fine roots. Bakker (1999) observed only an increase in $\mathrm{Ca}$ in the fine roots after liming. Therefore, fine roots have, at least for some elements (e.g. $\mathrm{Ca}, \mathrm{Mg}, \mathrm{Mn}$ ), the ability to reflect the chemical conditions of the soil.

In soils, as well as in fine roots, strong interactions occurred between the elements $\mathrm{Ca}$ and $\mathrm{Mg}$ and between $\mathrm{Fe}$ and $\mathrm{Al}$. These were apparent before and after the wood ash treatment (except for $\mathrm{Ca}$ and $\mathrm{Mg}$ in fine roots before the treatment). This indicates that the 


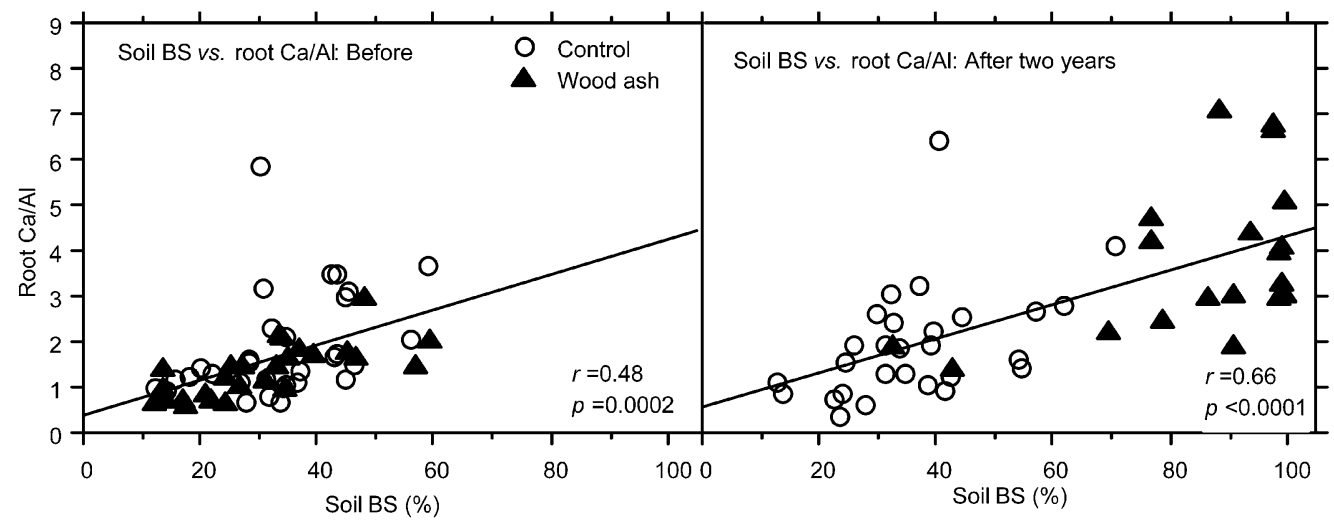

Figure 5. Relationship between soil base saturation (BS) and fine-root molar $\mathrm{Ca} / \mathrm{Al}$, as recorded in the control and the wood ash treatment plots before and after two years of wood ash treatment.

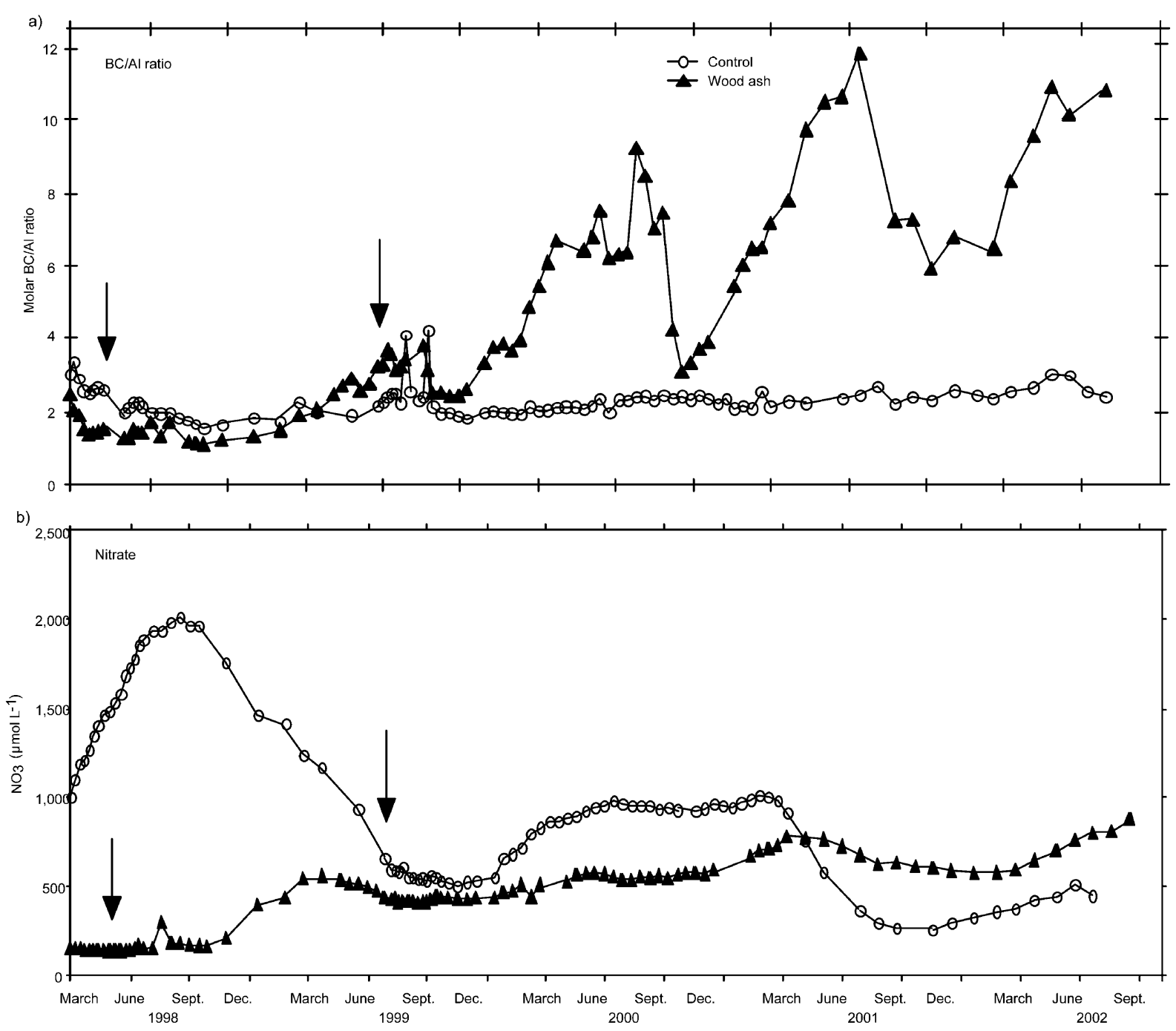

Figure 6. Courses (a) of the molar BC/Al ratio at a depth of 10-15 cm and (b) of the nitrate concentration at a depth of 70-75 cm in the soil solutions, as recorded in the control and the wood ash treatment plots over a period of four years (arrows = date of application of $4,000 \mathrm{~kg} \mathrm{ha}^{-1}$ wood ash). 
availability and uptake of $\mathrm{Ca}$ is strongly linked with that of $\mathrm{Mg}$, whereas the availability and uptake of $\mathrm{Al}$ tends to correlate with that of $\mathrm{Fe}$. This raises questions about the use of the $\mathrm{BC} / \mathrm{Al}$ or the $\mathrm{Ca} / \mathrm{Al}$ ratios where the assumption is made in the foreground that $\mathrm{Al}$ interferes with the uptake of $\mathrm{Ca}$ and $\mathrm{Mg}$ (Cronan and Grigal, 1995; Horst, 1995). Similar highly positive correlations between $\mathrm{Fe}$ and $\mathrm{Al}$ in fine roots were observed in an earlier study with coniferous trees from various forest stands in Switzerland (Brunner et al., 2002).

Acidifying pollutants pose a potential threat to the environment. To monitor them ecological assessment indicators based on the concept of critical loads of acidity are used to document the extent and potential health risks associated with these stresses. The main indicator is the molar $\mathrm{BC} / \mathrm{Al}$ ratio of the soil solution (Sverdrup and Warfvinge, 1993). The threshold value is 1 , which represents a $50 \%$ risk of the soil system suffering Al stress (Cronan and Grigal, 1995). Using this molar BC/Al ratio of the soil solution, an increase in the soil acidification was documented over a period of 10 years at a sensitive forest site in southern Switzerland (Blaser et al., 1999). With the wood ash application in the present study, the molar $\mathrm{BC} / \mathrm{Al}$ ratio of the soil solution at a soil depth of $10-15 \mathrm{~cm}$ increased within the first two years from about 1 to 6 . The increase was still ongoing after four years.

Additional indicators of soil acidification in forest ecosystems include the soil $\mathrm{pH}$ (threshold 4) and BS (threshold 15\%) of the soil matrix, and the molar $\mathrm{Ca} / \mathrm{Al}$ ratio of the fine roots (threshold 0.2 ) and of the current foliage (threshold 12.5) of the trees (Cronan and Grigal, 1995; Hettelingh and de Vries, 1992). Whereas in the present study the critical threshold of BS was exceeded in about $10 \%$ of the samples before the wood ash application, it was not exceeded after the application. The mean BS of the topsoil increased from about $30 \%$ to $90 \%$. Similarly, the mean soil $\mathrm{pH}$ increased from about 3 to 5 , and the mean molar $\mathrm{Ca} / \mathrm{Al}$ ratio of the fine roots increased from about 2 to 4 . Overall, all below-ground indicators of soil acidification responded positively to the wood ash application within two years. Only the molar $\mathrm{Ca} / \mathrm{Al}$ ratio in the current needles did not change within the investigated period. Similar results were obtained in a study from northern Germany, were no alterations in the concentrations of the elements of pine needles were observed (Ludwig et al., 2002). However, the needle chemistry of young trees might react significantly as seen in a field study with Norway spruce (Arvidsson and Lund- kvist, 2003) or in a greenhouse study with European chestnut (Zysset et al., 1996).

An application of wood ash also induces an increase in the microbial activity in the soil. This can result in a release of nitrate from the mineralisation of organic matter. Although $\mathrm{CO}_{2}$ evolution and the biomass of microbes increased after wood ash was added (Zimmermann and Frey, 2002), enhanced nitrate concentrations were not recorded in the soil solution except below the rooting zone at a depth of $75-80 \mathrm{~cm}$, where a slight increase was observed. An increase in $\mathrm{N}$ uptake by fine roots as measured with ${ }^{15} \mathrm{~N}$ was not found (Genenger et al., 2003a). In a study in northern Germany, however, an increase in nitrate was observed at all the soil depths investigated, but concentrations were well below the German legal limit (Ludwig et al., 2002).

Another potential risk of applying wood ash is an increase in heavy metals which are brought in either by the wood ash or as a result of the exchange and mineralisation processes in the soil. The wood ash application did mean a heavy metal input, although it was relatively low (about $2 \mathrm{~kg} \mathrm{ha}^{-1}$ of $\mathrm{Zn}$ and $\mathrm{Cu}$, $0.2 \mathrm{~kg} \mathrm{ha}^{-1}$ of $\mathrm{Ni}, \mathrm{Pb}, \mathrm{Cr}$, and $0.02 \mathrm{~kg} \mathrm{ha}^{-1} \mathrm{Cd}, \mathrm{Co}$, and Mo). Enhanced concentrations of heavy metals in the plots treated with wood ash were not recorded in the soil solution, nor were they found in the soil matrix or in the tree fine roots (data not shown). Ludwig et al. (2002) observed only a slight translocation of $\mathrm{Pb}$. Rumpf et al. (2001) claimed there was a slight increase in $\mathrm{Zn}$ concentrations, and Arvidsson and Lundkvist (2003) measured a tendency for higher concentrations of Cd levels only. Lodenius (2003) also observed no higher concentrations of $\mathrm{Cd}$, and concluded that, while $\mathrm{Cd}$ reserves increase in the soil, they remain in a biologically unavailable form.

\section{Concluding remarks}

Modern forest management aims to make forest ecosystems sustainable and to counteract the effects of potential adverse environmental impacts, e.g. by replacing lost nutrients (De Vries et al., 2003; Khanna and Medeira, 2002). Here we show that the application of wood ash to a forest ecosystem mitigates all belowground indicators of soil acidification. As wood ash contains no nitrogen, the risk of accelerated nitrate leaching is minimised, as is the risk of an increase in heavy metal concentrations, provided that untreated wood is used as the source of the wood ash. In com- 
parison to liming to abate soil acidification, wood ash application presents a sustainable solution to recycle of nutrients with the exclusion of nitrogen. It returns the nutrients to forest ecosystems after they have been removed by timber or fuel-wood harvesting. This suggests that the recycling of wood ash could be an integral part of sustainable forest management because it closes the nutrient cycle and reverses soil acidification. Ironically, the return of wood ash to forests is an illegal activity in Switzerland, where forest legislation prohibits the use of any fertilisers, additives, or agricultural or industrial by-products. The results of this study may help to establish a complete life cycle assessment for fuel wood as a basis for reforming this legislation.

\section{Acknowledgements}

We would like to thank M. Genenger, D. Hallenbarter, B. Frey, M. Bundt, S. Brodbeck and R. Köchli for their skilful work in the laboratory and the field, we also are grateful to J. Luster's team in the WSL's soil chemistry laboratory, and D. Pezzotta's in the WSL's central analytical laboratory for their support. W. Landolt and P. Bleuler were very helpful in establishing and maintaining the experimental set-up of the HARWA experiment in the field. We thank the village and the forestry service of Unterehrendingen, who kindly allowed us to perform the study in their district, we thank J. Innes (University of British Columbia, Vancouver), P. Brang, C. Matter, and S. Dingwall for improving the manuscript. The project was funded by the Swiss Federal Office for Education and Science (BBW) and the Swiss Agency for the Environment, Forests and Landscape (BUWAL) as part of the COST E6 Eurosilva Project 'Forest tree physiology research'.

\section{References}

Arvidsson H and Lundkvist H 2002 Needle chemistry in young Norway spruce stands after application of crushed wood ash. Plant Soil 238, 159-174.

Arvidsson H and Lundkvist H 2003 Effects of crushed wood ash on soil chemistry in young Norway spruce stands. For. Ecol. Manage. 176, 121-132.

Badoux E 1983 Ertragstafeln für die Fichte in der Schweiz. EAFV, Birmensdorf, Switzerland.

Bakker M R 1999 Fine-root parameters as indicators of sustainability of forest ecosystems. For. Ecol. Manage. 122, 7-16.

Blaser P, Zysset M, Zimmermann S and Luster J 1999 Soil acidification in southern Switzerland between 1987 and 1997: A case study based on the critical load concept. Environ. Sci. Technol. 33, 2383-2389.

Brunner I, Rigling D, Egli S and Blaser P 1999 Response of Norway spruce seedlings in relation to chemical properties of forest soils. For. Ecol. Manage. 116, 71-81.

Brunner I, Brodbeck S and Walthert L 2002 Fine root chemistry, starch concentration, and 'vitality' of subalpine conifer forests in relation to soil pH. For. Ecol. Manage. 165, 75-84.

Bundt M, Widmer F, Pesaro M, Zeyer J and Blaser P 2001a Preferential flow paths: biological 'hot spots' in soils. Soil Biol. Biochem. 33, 729-738.

Bundt M, Zimmermann S, Blaser P and Hagedorn F 2001b Sorption and transport of metals in preferential flow paths and soil matrix after the addition of wood ash. Eur. J. Soil Sci. 52, 423-431.

Cronan C and Grigal D F 1995 Use of calcium/aluminum ratios as indicators of stress in forest ecosystems. J. Environ. Qual. 24, 209-226.

De Vries W, Vel E, Reinds G J, Deelstra H, Klap J M, Leeters E E J M, Hendriks C M A, Kerkvoorden M, Landmann G, Herkendell J, Haussmann T and Erisman J W 2003 Intensive monitoring of forest ecosystems in Europe. 1. Objectives, set-up and evaluation strategy. For. Ecol. Manage. 174, 77-95.

Driscoll C T, Lawrence G B, Bulger A J, Butler T J, Cronan C S, Eagar C, Lambert K F, Likens G E, Stoddard J L and Weathers K C 2001 Acidic deposition in the northeastern United States: Sources and inputs, ecosystem effects, and management strategies. BioScience 51, 180-198.

Ellenberg H and Klötzli F 1972 Waldgesellschaften und Waldstandorte. Mitt. Eidg. Anst. Forstl. Versuchswes. 48, 587-930.

Eriksson H M 1998 Short-term effects of granulated wood ash on forest soil chemistry in SW and NE Sweden. Scand. J. For. Res. Suppl. 2, 43-55.

Fowler D, Cape N, Coyle M, Flecaard C, Kuylenstierna J, Hicks K, Derwent D, Johnson C and Stevenson D 1999 The global exposure of forests to air pollution. Wat. Air Soil Pollut. 116, 5-32.

Frühwald A 1995 LCA - a challenge for forestry and forest products industry. In Life-cycle analysis - A challenge for forestry and forest industry. Eds. A Frühwald and B Solberg. pp. 9-14. EFIProceeding No. 8, Joensuu, Finland.

Genenger M, Jaeggi M, Siegwolf R, Chalot M, Frossard E and Brunner I 2003a Rapid ${ }^{15} \mathrm{~N}$ uptake and metabolism in fine roots of Norway spruce. Trees 17, 144-152.

Genenger M, Zimmermann S, Frossard E and Brunner I 2003b The effects of fertiliser or wood ash on nitrate reductase activity in Norway spruce fine roots. For. Ecol. Manage. 175, 413-423.

Genenger M, Zimmermann S, Hallenbarter D, Landolt W, Frossard E and Brunner I 2003c Fine root growth and element concentrations of Norway spruce as affected by wood ash and liquid fertilisation. Plant Soil 255, 253-264.

Hahn G and Marschner H 1998 Cation concentration of short roots of Norway spruce as affected by acid irrigation and liming. Plant Soil 199, 23-27.

Hallenbarter D, Landolt W, Bucher J B and Schütz J P 2002 Effects of wood ash and liquid fertilization on the nutritional status and growth of Norway, spruce (Picea abies (L.) Karst.). Forstwiss. Centralbl. 121, 240-249.

Heim A, Luster J, Brunner I, Frey B and Frossard E 1999 Effects of aluminium treatment on Norway spruce roots: Aluminium binding forms, element distribution, and release of organic acids. Plant Soil 216, 103-116.

Hettelingh J-P and de Vries W 1992 Mapping Vademecum. Report No. 259101002, National Institute of Public Health and Environmental Protection, Bilthoven. 
Horst W H 1995 The role of the apoplast in aluminum toxicity and resistance of higher plants: A review. Z. Pflanzenern. Bodenk. 158, 419-428.

Khanna P K and Madeira M 2002 Sustainability of forest soils. For. Ecol. Manage. 172, 1-2.

Lodenius M 2003 Cadmium concentrations in a boreal forest ecosystem after application of wood ash. Bull. Environ. Contam. Toxicol. 71, 776-781.

Ludwig B, Rumpf S, Mindrup M, Meiwes K-J and Khanna P K 2002 Effects of lime and wood ash on soil-solution chemistry, soil chemistry and nutritional status of a pine stand in Northern Germany. Scand. J. For. Res. 17, 225-237.

Marschner H 1995 Mineral nutrition of higher plants. Academic Press, London.

Noger D, Felber H and Pletscher E 1996 Verwertung und Beseitigung von Holzaschen. Schriftenreihe Umwelt Nr. 269, BUWAL, Bern, Switzerland.

Olsson B A, Bengtsson J and Lundkvist H 1996 Effects of different forest harvest intensities on the pools of exchangeable cations in coniferous forest soils. For. Ecol. Manage. 84, 135-147.

Palmer S M and Driscoll C T 2002 Acidic deposition - Decline in mobilization of toxic aluminium. Nature 417, 242-243.

Rodhe H, Dentener F and Schulz M 2002 The global distribution of acidifying wet deposition. Environ. Sci. Technol. 36, 4382-4388.
Rumpf S, Ludwig B and Mindrup M 2001 Effect of wood ash on soil chemistry of a pine stand in Northern Germany. J. Plant Nutr. Soil Sci. 164, 569-575.

Sharpe W E 2002 Acid deposition explains sugar maple decline in the east. Bioscience 52, 4-5.

Sverdrup H and Warfvinge P 1993 The effect of soil acidification on the growth of trees, grass, herbs as expressed by the $(\mathrm{Ca}+\mathrm{Mg}+\mathrm{K}) / \mathrm{Al}$ ratio. Rep. in Ecology and Environmental Engineering 2. Lund University, Department of Chemical Engineering II, Lund.

Werner F, Althaus H-J and Richter K 2002 Post-consumer wood in environmental decision-support tools. Schweiz. Z. Forstwes. $153,97-106$.

Zimmermann S and Frey B 2002 Soil respiration and microbial properties in an acid forest soil: effects of wood ash. Soil Biol. Biochem. 34, 1727-1737.

Zysset M, Brunner I, Frey B and Blaser P 1996 Response of European chestnut to varying calcium/aluminum ratios. J. Environ. Qual. 25, 702-708.

Section editor: P. M. Attiwill 